\title{
Xeroderma Pigmentosum Variant Type
}

National Cancer Institute

\section{Source}

National Cancer Institute. Xeroderma Pigmentosum Variant Type. NCI Thesaurus. Code C141367.

A type of xeroderma pigmentosum resulting from mutation(s) in the POLH gene, encoding DNA polymerase eta. This form of the disease is characterized by normal DNA excision repair, but defective post-replication repair of DNA at UV-damaged sites. 